OPEN ACCESS

Edited by:

George C. Tsokos, Harvard Medical School, USA

Reviewed by:

Stamatis-Nick Liossis, University of Patras Medical School,

Greece

Antonio La Cava, University of California Los Angeles,

*Correspondence:

Thomas L. Rothstein tr@nshs.edu

Specialty section: This article was submitted to B Cell

Biology,

a section of the journal

Frontiers in Immunology

Received: 19 February 2016

Accepted: 21 March 2016

Published: 07 April 2016

Citation:

Rothstein TL (2016) Natural

Antibodies as Rheostats for

Susceptibility to Chronic Diseases in the Aged.

Front. Immunol. 7:127.

doi: 10.3389/fimmu.2016.00127

\section{Natural Antibodies as Rheostats for Susceptibility to Chronic Diseases in the Aged}

\author{
Thomas L. Rothstein* \\ Center for Oncology and Cell Biology, The Feinstein Institute for Medical Research, Manhasset, NY, USA
}

Natural antibodies are spontaneously produced in the absence of infection or immunization, and are both anti-microbial and autoreactive. Autoreactive natural antibodies can bind noxious molecules, such as those involved in clinical situations of atherosclerosis (oxLDL), malignancy (NGcGM3), and neurodegeneration (amyloid, tau) and can affect the fate of their targets or the cells bearing them to maintain homeostasis. Clinically relevant natural antibodies have been shown to decline with advancing age in those few situations where measurements have been made. Consistent with this, human B-1 cells that are thought to be responsible for generating natural antibodies also decline with advancing age. These findings together suggest that an age-related decline in amount or efficacy of homeostatic natural antibodies is associated with relative loss of protection against molecules involved in several diseases whose incidence rises in the older age population, and that those individuals experiencing greatest loss are at greatest risk. In this view, natural antibodies act as rheostats for susceptibility to several age-related diseases. These considerations suggest that administration of natural antibodies, or of factors that maintain B-1 cells and/or enhance production of natural antibodies by B-1 cells, may serve to counteract the onset or progression of age-related chronic illness.

Keywords: human B cells, B-1 cells, natural antibody

\section{INTRODUCTION}

Natural antibody represents immunoglobulin that is spontaneously and constitutively secreted in the absence of infection or immunization. Natural antibody is present in animals and humans, and is thought to comprise the bulk of resting IgM, along with portions of isotype-switched IgA and IgG. Natural antibody differs from adaptive antibody in many ways, importantly including repertoire and function. Much natural antibody is anti-microbial and forms a preexisting shield against infection that provides a primary layer of protection during the lag period required for germinal center formation and adaptive antibody production (1-5). Natural antibody also tends to be autoreactive (6-9) and performs a second beneficial function in housekeeping and homeostatic activity that speeds elimination of dying cell debris and noxious molecular species $(4,10-17)$. In this way, potentially inflammatory and/or toxic agents are removed before direct tissue injury can occur.

Natural antibody is generated for the most part by a relatively small but unique subpopulation of B cells termed B-1 cells, first recognized in 1982, that is developmentally distinct (18-20). The origin and function of B-1 cells have been most extensively studied in mice, where B-1 cells are readily identified by a clear set of phenotypic markers (B220loCD5 $\left.{ }^{+} \mathrm{CD} 23^{-} \mathrm{CD} 43^{+} \mathrm{IgMhiIgDlo}\right)$. 
For some time, the status of human B-1 cells has been uncertain, and the existence of human B-1 cells has been debated. However, a new phenotypic profile for B-1 cells in human peripheral blood was recently reported $\left(\mathrm{CD} 19^{+} \mathrm{CD} 20^{+} \mathrm{CD} 27^{+} \mathrm{CD} 38 \operatorname{modCD} 43^{+}\right.$ $\left.\mathrm{CD}^{-}\right)$(21-23) and, despite some controversy (24-27), this profile has gained acceptance and has been utilized by a number of investigators in translational studies of specific disease states $(25,26,28-31)$.

The natural antibodies produced by B-1 cells differ in sequence from adaptive antibodies produced by conventional B (B-2) cells, which in turn dictates repertoire and function. Mouse B-1 cell antibodies are more germ line-like in comparison to mouse B-2 cell antibodies by virtue of containing little or no somatic hypermutation and much reduced, or non-existent, $\mathrm{N}$-region addition $(15,32-34)$ both of which affect CDR3 domains that are major contributors to antigen binding. The lack of $\mathrm{N}$-addition appears to derive from the absence of terminal deoxynucleotidyl transferase (TdT) during mouse hematopoietic development early in life when the bulk of B-1 cells are generated (35). However, human B-1 cell antibodies often contain $\mathrm{N}$-addition, which likely reflects the presence of TdT throughout ontogeny in Homo sapiens (35). Like mouse B-1 cell antibodies, human B-1 cell antibodies contain little or no somatic hypermutation early in life (21), but acquire somatic mutation as time goes on, although some difference in this measure between B-1 and B-2 cell antibodies continues into adulthood (23). Because B-1 cell antibodies tend to reflect sequences delineated in the genome with little alteration, especially in mice, it has been suggested that the B-1 cell repertoire is "tuned" over evolutionary time, obeying Darwinian precepts such that sequences functioning to promote survival are retained (10). In this view, B-1 cell antibodies represent the best functioning antibodies for the roles that they fulfill.

\section{HUMAN NATURAL ANTIBODIES RECOGNIZE MOLECULES ASSOCIATED WITH DISEASES OF AGING}

Human natural antibodies directed against a variety of molecules with clinical significance have been identified. Three specific disease areas are illustrative, and these are three of the most common, distressing, and burdensome diseases associated with aging. (1) Atherosclerosis : healthy individuals commonly express IgM antibodies that bind oxidized low-density lipoproteins (oxLDL) (36). Oxidized LDLs arise from non-enzymatic processes, accumulate within vessel walls, and contribute to plaque formation and inflammation that together drive the disease process of atherosclerosis, resulting in cardiovascular events that can be lethal (37). One type of anti-oxLDL natural antibody binds an oxidized form of the major lipoprotein, apolipoprotein B100 (38-40). (2) Malignancy: healthy individuals commonly express antibodies that bind $\mathrm{N}$-glycolylneuraminyl-lactosylceramide (NGcGM3) (41). NGcGM3 is not thought to be produced in human tissues due to an inactivating insertional mutation of cytidine monophosphate- $N$-acetylneuraminic acid hydroxylase (CMAH) that occurred evolutionarily after divergence of humankind from great apes, about 2.8 million years ago $(42,43)$.
However, NGcGM3 is present in humans, presumably acquired exogenously by dietary intake, and for reasons that are as yet unclear is concentrated many fold in the membranes of some tumors, prominently including the malignant cells of lung cancer (44). (3) Neurodegeneration: healthy individuals commonly express antibodies that bind amyloid and tau proteins (45-48). Abnormal plaques (amyloid) and tangles (tau) of these proteins have been implicated in the pathogenesis of Alzheimer's Disease, in which protein aggregates result in neuronal dysfunction, and enhanced phosphorylation may play a role in this abnormal protein behavior and disease pathogenesis (49).

\section{DISEASE-ASSOCIATED NATURAL ANTIBODIES ARE FUNCTIONAL}

Natural antibodies directed against antigens associated with these three classes of disease appear to be functional. (1) In mice, a number of adoptive transfer experiments with $A p o e^{-/-}$recipients have led to the generally accepted paradigm that B-1 cells and the IgM antibodies they produce are atheroprotective, whereas B-2 cells and the IgG antibodies they produce are atherogenic $(50,51)$. Less invasive studies have been carried out with people, and it has been shown that human IgM anti-oxLDL is inversely correlated with cardiovascular and carotid disease (12, 38, 39, 52-54), whereas IgG has been found to be positively correlated with atherosclerosis $(12,52,55-60)$ or not correlated at all with vessel pathology $(40,61-64)$. The mechanism appears to involve inhibition of oxLDL uptake by macrophages $(65,66)$. In a recent study, human serum antibodies directed against a methylglyoxal (MGO) modified apolipoprotein B100 peptide were examined. The levels of IgM antibodies in healthy individuals aged 63-68 were found to be inversely correlated with cardiovascular events occurring during the subsequent 15 years; in contrast, the levels of IgG antibodies were not correlated with subsequent cardiovascular events (67). Thus, in both mouse and human, natural IgM antibodies against oxLDL, appear to counteract the development of atherosclerosis. (2) Human natural anti-NGcGM3 antibodies have been shown to specifically bind and eliminate malignant cells bearing NGcGM3. This tumor cell destruction by anti-NGcGM3 antibodies occurs through both a complement-dependent mechanism and an oncosis-like, complement-independent mechanism $(41,68,69)$. Somewhat akin to the correlative results noted above with respect to MGO-modified apoB100 peptide, patients with lung cancer lack or have very low levels of anti-NGcGM3 antibodies (41). Separately, an anti-idiotypic antibody vaccine (racotumomab) that displays the "internal image" of NGcGM3 has been developed to stimulate production of anti-NGcGM3 antibodies (69-71). In a recent clinical trial for maintenance treatment after first line chemotherapy in non-small cell lung cancer patients, racotumomab significantly prolonged overall survival and progression free survival, and those patients experiencing the greatest antibody response had the best outcomes $(69,72)$. Thus, natural and elicited cytotoxic antibodies against NGcGM3 appear to protect against the onset and/or ameliorate the course of lung cancer. (3) Human natural antibodies against amyloid and tau have been proposed as agents that might oppose 
and/or treat Alzheimer's neurodegeneration. As with the inverse correlation between serum levels of natural antibodies and the disease states of atherosclerosis and malignancy discussed above, natural anti-amyloid antibodies have been shown to be relatively diminished in patients with Alzheimer's Disease (46, 73-75). These natural anti-amyloid antibodies have been shown to diminish the burden of aggregated proteins and improve cell viability in vitro $(45,46,76,77)$. In animal studies, passive administration of antibodies against amyloid and tau has in each case depleted abnormal proteins from the brain and improved pathology and/ or behavioral parameters $(76,78-81)$. In recent clinical trials, passive administration of monoclonal antibodies against amyloid protein failed to produce improvement in cognition or function (82-85). This failure of clinical improvement in anti-amyloid trials to date, despite preclinical data showing diminished protein aggregation, remains unexplained, but may suggest the utility of alternative anti-tau treatment. Regardless, these results indicate that circulating antibodies can affect aggregation and alter deposits of abnormal, pathological amyloid and tau proteins.

\section{CLINICALLY RELEVANT NATURAL ANTIBODIES ARE DIMINISHED OR LESS EFFECTIVE WITH INCREASING AGE AND DISEASE}

In each of the three clinical entities discussed above, natural antibodies that recognize disease-associated epitopes are diminished in affected patients. There are several potential explanations for these inverse correlations, among which is the possibility that the absence of homeostatic antibodies increases the risk of developing disease. This is perhaps most directly suggested by the prospective study of natural antibodies that recognize modified apoB100 and the associated subsequent risk of cardiovascular events, discussed above. These diseases of atherosclerosis, malignancy, and neurodegeneration are all more common with increasing age. If natural antibodies are involved in opposing disease pathogenesis and/or disease progression, it would be expected that levels of disease-related natural antibodies would be found to be diminished with advancing age. In fact, an age-related decline has been documented for natural antibodies directed against NGcGM3 (41), and for natural antibodies directed against amyloid (46). Thus far, the relationship between natural antibodies against oxidized apoB100 and age has not been examined.

\section{B-1 CELLS GENERATE HOMEOSTATIC ANTIBODIES}

In mice, natural antibodies are predominantly, if not exclusively, generated by B-1 cells. The recent phenotypic identification of human B-1 cells raises the question of whether this population is responsible for producing human natural antibodies, especially those related to disease. This has been evaluated for atherosclerosis-predictive/-protective IgM antibodies against MGO-modified apoB100. Among human B-1 cell, memory B cell, preplasmablast and plasmablast culture supernantants, natural IgM anti-MGO-apoB100 antibodies were generated predominantly by human B-1 cells (67). Similarly, B-1 cells are responsible for producing natural anti-NGcGM3 antibodies in mice (44). However, human B-1 cells have not yet been tested for production of antibodies neither against NGcGM3 nor against amyloid and tau.

\section{AGE-RELATED CHANGES IN NATURAL ANTIBODIES LIKELY RELATE TO AGE- RELATED CHANGES IN B-1 CELLS}

To the extent that human B-1 cells are the origin of diseaserelated homeostatic natural antibodies, then a change in B-1 cells may underlie the decline that occurs with advancing age. To address this possibility, B-1 cell and other B cell populations were enumerated in peripheral blood of healthy adult volunteers over a wide age range. This study showed an agerelated decline in B-1 cells (21). Other B cell populations did not change with age. Thus, B-1 cell numbers are age-sensitive. Although some investigators have reported an age-related decline in memory B cells, others have not (86-89), but B-1 cells were not differentiated from $\mathrm{CD} 27^{+}$memory B cells in earlier studies.

Beyond numbers, there is some evidence in mouse studies that the B-1 cell repertoire changes with age (90). In a careful study involving deep sequencing, Ghosn et al. showed that selection operates on the B-1 cell repertoire as mice mature (91). Consistent with this, the avidity of natural anti-amyloid antibodies is diminished in patients with Alzheimer's Disease as compared to healthy controls (75). Thus, as a result of declining B-1 cell numbers, or a change in B-1 cell repertoire, or both, natural antibody deteriorates, which appears to be accompanied by a loss of the protection, especially homeostatic protection, that natural antibody affords.

\section{THE RHEOSTAT HYPOTHESIS FOR B-1 CELL NATURAL ANTIBODIES}

Weaving these different strands of evidence together, there is reason to hypothesize, as a general paradigm, that: (1) an age-related decline in amount and/or efficacy of homeostatic natural antibodies is in turn associated with relative loss of protection against molecules involved in several diseases whose incidence rises in the older age population; and, (2) those individuals experiencing the greatest loss in amount and/or efficacy of homeostatic natural antibodies are at greatest risk. In this view, natural antibodies act as rheostats for susceptibility to several age-related diseases that are associated with accumulation of noxious molecules or involve unique molecular targets, or both. Extrapolation from this point suggests the possibility that administration of disease-opposing natural antibodies or of factors that maintain B-1 cells and/or enhance production of disease-opposing natural antibodies by B-1 cells could serve to counteract the onset or progression of age-related chronic illness. 


\section{WHY ARE NATURAL ANTIBODIES RELEVANT TO DISEASES OF THE ELDERLY PRESENT BEYOND THE AGE OF REPRODUCTION?}

According to Darwinian principles, there is no advantage to counteracting diseases whose onset occurs after reproductive age. In this sense, then, results in both the mouse and human systems raise the question of why natural antibodies that protect against age-associated diseases are retained in evolution. This likely results from polyreactivity of B-1 cell natural antibodies, and antigenic mimicry of B-1 cell natural antibody targets, as illustrated graphically by mouse T15/E06 $(11,92)$. T15 is a completely germ-line antibody that arises in many mouse strains, first identified by its recognition of phosphorylcholine, an antigenic determinant found on pneumococci and other microbes. E06 is a completely germ-line antibody identified by its binding to oxidized LDL. T15 and E06 are, in fact, one-and-the-same; they are identical antibodies that protect against pneumococcal infection and affect the disposition of oxLDL (93). Moreover, human antibodies with these kinds of specificities appear early in life. This is highlighted by reports that IgM anti-oxLDL antibodies are found in umbilical cord blood samples and in blood samples from preterm and full-term infants $(94,95)$. These antibodies block the uptake of oxLDL by macrophages and are often germ line in heavy chain sequence (95). So natural antibodies capable of influencing atherosclerosis later in life appear early in ontogeny and seem to exist by virtue of a combination of similarity between antigens on bacteria and oxidized lipids and polyreactivity of B-1 cell-derived natural antibodies. The same is likely true of other natural antibodies.

\section{DO NATURAL ANTIBODIES ARISE SPONTANEOUSLY OR ARE THEY STIMULATED BY SELF-ANTIGENS?}

Mature B-1 cells secrete antibody spontaneously and constitutively, in the absence specific antigen engagement, which fails to generate typical signs of BCR signaling and activation in these cells (96). However, the BCR may play a role early on. Studies in mice indicate that B-1 cell development is enhanced by antigen engagement, the inverse of antigen-induced apoptosis in nascent B-2 cells $(97,98)$. The relevant antigens may be self-antigens, inasmuch as B-1 cell development is not disturbed in germ-free mice lacking foreign antigens (91). NGcGM3 would appear to contradict this paradigm because it cannot be a self-antigen in the human species that lacks CMAH and is incapable of generating this ganglioside. However, the germ-line antibody, 4ac, which binds myelin oligodendrocyte glycoprotein (MOG), a central nervous system target for EAE (experimental allergic encephalomyelitis), is identical to the germ-line anti-NGcGM3 antibody, P3, and so cross-reactivity with self components may explain the existence of natural antibodies against NGcGM3 (99). Further, potential transfer of NGcGM3 across the placenta and in mother's milk at early stages of fetal/neonatal development is unknown. Overall, the degree to which the B-1 cell repertoire is shaped by self-antigens as opposed to "foreign" antigens remains a question yet to be fully resolved. In light of the polyreactivity and antigen mimicry discussed above, the determinants of the B-1 cell repertoire are likely to have an important influence on the level of homeostatic protection provided by B-1 cell natural antibody and may be responsible, at least in part, for the variation in protective antibody noted among older individuals.

\section{OTHER QUESTIONS REMAIN}

B-1 cells in mouse and human can isotype switch and secrete natural antibodies that are IgA and $\operatorname{IgG}$ as well as $\operatorname{IgM}(23,100,101)$. The degree to which this happens may be important in assessing the level of homeostatic protection afforded by natural antibodies. For example, IgM anti-oxLDL antibodies protect against atherosclerosis in mice and correlate with protection against cardiovascular events in humans, whereas IgG anti-oxLDL antibodies do not. However, it is unknown at present whether IgG anti-oxLDL antibodies originate from B-1 cells and whether, if they do, they can be as protective as IgM anti-oxLDL antibodies.

In addition, other $B$ cell populations, such as marginal zone B cells and IgM memory $\mathrm{B}$ cells, have been proposed as contributors to the pool of natural antibodies (102-106). At present it is unknown to what extent, if any, protective homeostatic antibodies derive from these populations but this could be relevant to the extent that enhancement of homeostatic natural antibody producing $B$ cell populations becomes a prophylactic or therapeutic maneuver in the future.

\section{CONCLUSION/RHEOSTAT REDUX}

To summarize, it is proposed that many chronic diseases associated with aging, including atherosclerosis, cancer, and neurodegeneration, and possibly others, take place against a background of greater or lesser homeostatic protection provided by B-1 cell-derived natural antibodies that decline with advancing age due to a decrease in the B-1 cell population and/or an alteration in the B-1 cell repertoire. There is much to be learned regarding the development and function of B-1 cells and the nature of homeostatic natural antibodies, and changes that occur in both B-1 cells and natural antibodies with advancing age. As this information is acquired, it is proposed that the onset and/or course of several chronic diseases of aging might be favorably altered by therapies that maintain or enhance the native B-1 cell population and/or that replace or add exogenous natural antibodies.

\section{AUTHOR CONTRIBUTIONS}

TR conceived and wrote the perspective based on work from his laboratory and others over many years time.

\section{ACKNOWLEDGMENTS}

The author gratefully acknowledges long-term support for B-1 cell studies from the National Institutes of Health (AI029690) and more recent support from the NIH (AI099517 and AI095787) and the Lupus Research Institute. The author thanks members of his laboratory group over the years for their help in formulating the ideas expressed herein, and thanks Drs. Nichol E. Holodick, Tam D. Quach, and Gregg J. Silverman for critical review of the manuscript. 


\section{REFERENCES}

1. Ochsenbein AF, Fehr T, Lutz C, Suter M, Brombacher F, Hengartner H, et al. Control of early viral and bacterial distribution and disease by natural antibodies. Science (1999) 286:2156-9. doi:10.1126/science.286.5447.2156

2. Baumgarth N, Herman OC, Jager GC, Brown LE, Herzenberg LA, Chen J. B-1 and B-2 cell-derived immunoglobulin $\mathrm{M}$ antibodies are nonredundant components of the protective response to influenza virus infection. J Exp Med (2000) 192:271-80. doi:10.1084/jem.192.2.271

3. Boes M, Prodeus AP, Schmidt T, Carroll MC, Chen J. A critical role of natural immunoglobulin $\mathrm{M}$ in immediate defense against systemic bacterial infection. J Exp Med (1998) 188:2381-6. doi:10.1084/jem.188.12.2381

4. Briles DE, Nahm M, Schroer K, Davie J, Baker P, Kearney J, et al. Antiphosphocholine antibodies found in normal mouse serum are protective against intravenous infection with type 3 Streptococcus pneumoniae. J Exp Med (1981) 153:694-705. doi:10.1084/jem.153.3.694

5. Haas KM, Poe JC, Steeber DA, Tedder TF. B-1a and B-1b cells exhibit distinct developmental requirements and have unique functional roles in innate and adaptive immunity to S. pneumoniae. Immunity (2005) 23:7-18. doi:10.1016/j.immuni.2005.04.011

6. Baccala R, Quang TV, Gilbert M, Ternynck T, Avrameas S. Two murine natural polyreactive autoantibodies are encoded by nonmutated germ-line genes. Proc Natl Acad Sci U S A (1989) 86:4624-8. doi:10.1073/pnas.86.12.4624

7. Hartman AB, Mallett CP, Srinivasappa J, Prabhakar BS, Notkins AL, SmithGill SJ. Organ reactive autoantibodies from non-immunized adult BALB/c mice are polyreactive and express non-biased VH gene usage. $\mathrm{Mol}$ Immunol (1989) 26:359-70. doi:10.1016/0161-5890(89)90125-9

8. Lalor PA, Morahan G. The peritoneal Ly-1 (CD5) B cell repertoire is unique among murine B cell repertoires. Eur J Immunol (1990) 20:485-92. doi:10.1002/eji.1830200305

9. Klinman DM, Holmes KL. Differences in the repertoire expressed by peritoneal and splenic Ly-1 (CD5)+ B cells. J Immunol (1990) 144:4520-5.

10. Briles DE, Forman C, Hudak S, Claflin JL. Anti-phosphorylcholine antibodies of the T15 idiotype are optimally protective against Streptococcus pneumoniae. J Exp Med (1982) 156:1177-85. doi:10.1084/jem.156.4.1177

11. Shaw PX, Horkko S, Chang MK, Curtiss LK, Palinski W, Silverman GJ, et al. Natural antibodies with the T15 idiotype may act in atherosclerosis, apoptotic clearance, and protective immunity. J Clin Invest (2000) 105:1731-40. doi:10.1172/JCI8472

12. Tsimikas S, Brilakis ES, Lennon RJ, Miller ER, Witztum JL, McConnell JP, et al. Relationship of IgG and IgM autoantibodies to oxidized low density lipoprotein with coronary artery disease and cardiovascular events. J Lipid Res (2007) 48:425-33. doi:10.1194/jlr.M600361-JLR200

13. Soto Y, Conde H, Aroche R, Brito V, Luaces P, Nasiff A, et al. Autoantibodies to oxidized low density lipoprotein in relation with coronary artery disease. Hum Antibodies (2009) 18:109-17. doi:10.3233/HAB-2009-0202

14. Kyaw T, Tay C, Krishnamurthi S, Kanellakis P, Agrotis A, Tipping P, et al. Bla B lymphocytes are atheroprotective by secreting natural IgM that increases IgM deposits and reduces necrotic cores in atherosclerotic lesions. Circ Res (2011) 109:830-40. doi:10.1161/CIRCRESAHA.111.248542

15. Hardy RR, Carmack CE, Shinton SA, Riblet RJ, Hayakawa K. A single VH gene is utilized predominantly in anti-BrMRBC hybridomas derived from purified Ly-1 B cells. Definition of the VH11 family. J Immunol (1989) 142:3643-51.

16. Pennell CA, Sheehan KM, Brodeur PH, Clarke SH. Organization and expression of VH gene families preferentially expressed by Ly-1+ (CD5) B cells. Eur J Immunol (1989) 19:2115-21. doi:10.1002/eji.1830191122

17. Chen Y,Park YB, PatelE, Silverman GJ. IgM antibodies to apoptosis-associated determinants recruit $\mathrm{Clq}$ and enhance dendritic cell phagocytosis of apoptotic cells. J Immunol (2009) 182:6031-43. doi:10.4049/jimmunol.0804191

18. Rothstein TL, Griffin DO, Holodick NE, Quach TD, Kaku H. Human B-1 cells take the stage. Ann N Y Acad Sci (2013) 1285:97-114. doi:10.1111/ nyas. 12137

19. Montecino-Rodriguez E, Leathers H, Dorshkind K. Identification of a B-1 B cell-specified progenitor. Nat Immunol (2006) 7:293-301. doi:10.1038/ni1301

20. Ghosn EE, Waters J, Phillips M, Yamamoto R, Long BR, Yang Y, et al. Fetal hematopoietic stem cell transplantation fails to fully regenerate the B-lymphocyte compartment. Stem Cell Rep (2015) 6:137-49. doi:10.1016/j. stemcr.2015.10.011
21. Griffin DO, Holodick NE, Rothstein TL. Human B1 cells in umbilical cord and adult peripheral blood express the novel phenotype CD20+CD27+CD43+CD70. J Exp Med (2011) 208:67-80. doi:10.1084/ jem.201014992084c

22. Griffin DO, Rothstein TL. Human B1 cell frequency: isolation and analysis of human B1 cells. Front Immunol (2012) 3:122. doi:10.3389/fimmu.2012.00122

23. Quach TD, Rodriguez-Zhurbenko N, Hopkins TJ, Guo X, Hernandez AM, Li W, et al. Distinctions among circulating antibody-secreting cell populations, including B-1 cells, in human adult peripheral blood. J Immunol (2016) 196(3):1060-9. doi:10.4049/jimmunol.1501843

24. Griffin DO, Holodick NE, Rothstein TL. Human B1 cells are CD3-: a reply to "A human equivalent of mouse B-1 cells?" and "The nature of circulating CD27+CD43+ B cells.” J Exp Med (2011) 208:2566-9. doi:10.1084/ jem. 20111761

25. Kraljevic K, Wong S, Fulcher DA. Circulating phenotypic B-1 cells are decreased in common variable immunodeficiency and correlate with immunoglobulin M levels. Clin Exp Immunol (2013) 171:278-82. doi:10.1111/ cei. 12008

26. Suchanek O, Sadler R, Bateman EA, Patel SY, Ferry BL. Immunophenotyping of putative human B1 B cells in healthy controls and common variable immunodeficiency (CVID) patients. Clin Exp Immunol (2012) 170:333-41. doi:10.1111/j.1365-2249.2012.04656.x

27. Li W, Batliwalla F, Rothstein TL. Human B-1 cells are not preplasmablasts: analysis of microarray data and other issues. Blood (2013) 122:3691-3. doi:10.1182/blood-2013-08-520031

28. Verbinnen B, Covens K, Moens L, Meyts I, Bossuyt X. Human CD20+CD43+CD27+CD5- B cells generate antibodies to capsular polysaccharides of Streptococcus pneumoniae. J Allergy Clin Immunol (2012) 130:272-5. doi:10.1016/j.jaci.2012.04.040

29. Leggat DJ, Khaskhely NM, Iyer AS, Mosakowski J, Thompson RS, Weinandy JD, et al. Pneumococcal polysaccharide vaccination induces polysaccharide-specific $\mathrm{B}$ cells in adult peripheral blood expressing CD19CD20CD3CD70CD27IgMCD43CD5. Vaccine (2013) 31:4632-40. doi:10.1016/j.vaccine.2013.07.030

30. Torring C, Petersen CC, Bjerg L, Kofod-Olsen E, Petersen T, Hollsberg P. The B1-cell subpopulation is diminished in patients with relapsing-remitting multiple sclerosis. J Neuroimmunol (2013) 262:92-9. doi:10.1016/j. jneuroim.2013.06.002

31. Moins-Teisserenc H, Busson M, Herda A, Apete S, Peffault de Latour R, Robin M, et al. CD19+CD5+ B cells and B1-like cells following allogeneic hematopoietic stem cell transplantation. Biol Blood Marrow Transplant (2013) 19:988-91. doi:10.1016/j.bbmt.2013.03.006

32. Gu H, Forster I, Rajewsky K. Sequence homologies, N sequence insertion and $\mathrm{JH}$ gene utilization in VHDJH joining: implications for the joining mechanism and the ontogenetic timing of Ly1 B cell and B-CLL progenitor generation. EMBO J (1990) 9:2133-40.

33. Forster I, Gu H, Rajewsky K. Germline antibody V regions as determinants of clonal persistence and malignant growth in the B cell compartment. EMBO $J$ (1988) 7:3693-703.

34. Pennell CA, Mercolino TJ, Grdina TA, Arnold LW, Haughton G, Clarke $\mathrm{SH}$. Biased immunoglobulin variable region gene expression by Ly-1 B cells due to clonal selection. Eur J Immunol (1989) 19:1289-95. doi:10.1002/ eji.1830190721

35. Payne KJ, Crooks GM. Immune-cell lineage commitment: translation from mice to humans. Immunity (2007) 26:674-7. doi:10.1016/j. immuni.2007.05.011

36. Binder CJ. Natural IgM antibodies against oxidation-specific epitopes. J Clin Immunol (2010) 30(Suppl 1):S56-60. doi:10.1007/s10875-010-9396-3

37. Hansson GK. Inflammation, atherosclerosis, and coronary artery disease. $N$ Engl J Med (2005) 352:1685-95. doi:10.1056/NEJMra043430

38. McLeod O, Silveira A, Fredrikson GN, Gertow K, Baldassarre D, Veglia F, et al. Plasma autoantibodies against apolipoprotein B-100 peptide 210 in subclinical atherosclerosis. Atherosclerosis (2014) 232:242-8. doi:10.1016/j. atherosclerosis.2013.11.041

39. Engelbertsen D, Anand DV, Fredrikson GN, Hopkins D, Corder R, Shah PK, et al. High levels of $\operatorname{IgM}$ against methylglyoxal-modified apolipoprotein B100 are associated with less coronary artery calcification in patients with type 2 diabetes. J Intern Med (2012) 271:82-9. doi: $10.1111 /$ j.1365-2796.2011.02411.x 
40. Fredrikson GN, Hedblad B, Berglund G, Alm R, Nilsson JA, Schiopu A, et al. Association between IgM against an aldehyde-modified peptide in apolipoprotein B-100 and progression of carotid disease. Stroke (2007) 38:1495-500. doi:10.1161/STROKEAHA.106.474577

41. Rodriguez-Zhurbenko N, Martinez D, Blanco R, Rondon T, Grinan T, Hernandez AM. Human antibodies reactive to NeuGcGM3 ganglioside have cytotoxic anti-tumor properties. Eur J Immunol (2013) 43:826-37. doi:10.1002/eji.201242693

42. Springer SA, Diaz SL, Gagneux P. Parallel evolution of a self-signal: humans and new world monkeys independently lost the cell surface sugar Neu5Gc. Immunogenetics (2014) 66:671-4. doi:10.1007/s00251-014-0795-0

43. Chou HH, Hayakawa T, Diaz S, Krings M, Indriati E, Leakey M, et al. Inactivation of CMP-N-acetylneuraminic acid hydroxylase occurred prior to brain expansion during human evolution. Proc Natl Acad Sci U S A (2002) 99:11736-41. doi:10.1073/pnas.182257399

44. Rodriguez-Zhurbenko N, Rabade-Chediak M, Martinez D, Grinan T, Hernandez AM. Anti-NeuGcGM3 reactivity: a possible role of natural antibodies and B-1 cells in tumor immunosurveillance. Ann N Y Acad Sci (2015) 1362:224-38. doi:10.1111/nyas.12827

45. Szabo P, Relkin N, Weksler ME. Natural human antibodies to amyloid beta peptide. Autoimmun Rev (2008) 7:415-20. doi:10.1016/j.autrev.2008.03.007

46. Britschgi M, Olin CE, Johns HT, Takeda-Uchimura Y, LeMieux MC, Rufibach $\mathrm{K}$, et al. Neuroprotective natural antibodies to assemblies of amyloidogenic peptides decrease with normal aging and advancing Alzheimer's disease. Proc Natl Acad Sci U S A (2009) 106:12145-50. doi:10.1073/pnas.0904866106

47. Rosenmann H, Meiner Z, Geylis V, Abramsky O, Steinitz M. Detection of circulating antibodies against tau protein in its unphosphorylated and in its neurofibrillary tangles-related phosphorylated state in Alzheimer's disease and healthy subjects. Neurosci Lett (2006) 410:90-3. doi:10.1016/j. neulet.2006.01.072

48. Terryberry JW, Thor G, Peter JB. Autoantibodies in neurodegenerative diseases: antigen-specific frequencies and intrathecal analysis. Neurobiol Aging (1998) 19:205-16. doi:10.1016/S0197-4580(98)00049-9

49. Ballard C, Gauthier S, Corbett A, Brayne C, Aarsland D, Jones E. Alzheimer's disease. Lancet (2011) 377:1019-31. doi:10.1016/S0140-6736(10)61349-9

50. Tsiantoulas D, Sage AP, Mallat Z, Binder CJ. Targeting B cells in atherosclerosis: closing the gap from bench to bedside. Arterioscler Thromb Vasc Biol (2015) 35:296-302. doi:10.1161/ATVBAHA.114.303569

51. Morris-Rosenfeld S, Lipinski MJ, McNamara CA. Understanding the role of B cells in atherosclerosis: potential clinical implications. Expert Rev Clin Immunol (2014) 10:77-89. doi:10.1586/1744666X.2014.857602

52. Mayr M, Kiechl S, Tsimikas S, Miller E, Sheldon J, Willeit J, et al. Oxidized low-density lipoprotein autoantibodies, chronic infections, and carotid atherosclerosis in a population-based study. JAm Coll Cardiol (2006) 47:2436-43. doi:10.1016/j.jacc.2006.03.024

53. Karvonen J, Paivansalo M, Kesaniemi YA, Horkko S. Immunoglobulin M type of autoantibodies to oxidized low-density lipoprotein has an inverse relation to carotid artery atherosclerosis. Circulation (2003) 108:2107-12. doi:10.1161/01.CIR.0000092891.55157.A7

54. Su J, Georgiades A, Wu R, Thulin T, de Faire U, Frostegard J. Antibodies of IgM subclass to phosphorylcholine and oxidized LDL are protective factors for atherosclerosis in patients with hypertension. Atherosclerosis (2006) 188:160-6. doi:10.1016/j.atherosclerosis.2005.10.017

55. Bui MN, Sack MN, Moutsatsos G, Lu DY, Katz P, McCown R, et al. Autoantibody titers to oxidized low-density lipoprotein in patients with coronary atherosclerosis. Am Heart $J$ (1996) 131:663-7. doi:10.1016/ S0002-8703(96)90268-9

56. Inoue T, Uchida T, Kamishirado H, Takayanagi K, Hayashi T, Morooka S. Clinical significance of antibody against oxidized low density lipoprotein in patients with atherosclerotic coronary artery disease. J Am Coll Cardiol (2001) 37:775-9. doi:10.1016/S0735-1097(00)01199-2

57. Lehtimaki T, Lehtinen S, Solakivi T, Nikkila M, Jaakkola O, Jokela H, et al. Autoantibodies against oxidized low density lipoprotein in patients with angiographically verified coronary artery disease. Arterioscler Thromb Vasc Biol (1999) 19:23-7. doi:10.1161/01.ATV.19.1.23

58. Maiolino G, Pedon L, Cesari M, Frigo AC, Barisa M, Rossitto G, et al. Antibodies to malondialdehyde oxidized low-density lipoproteins predict long term cardiovascular mortality in high risk patients. Int J Cardiol (2013) 168:484-9. doi:10.1016/j.ijcard.2012.09.165
59. Puurunen M, Manttari M, Manninen V, Tenkanen L, Alfthan G, Ehnholm C, et al. Antibody against oxidized low-density lipoprotein predicting myocardial infarction. Arch Intern Med (1994) 154:2605-9. doi:10.1001/ archinte.1994.00420220105012

60. Inoue $\mathrm{T}$, Uchida $\mathrm{T}$, Kamishirado H, Takayanagi K, Morooka S. Antibody against oxidized low density lipoprotein may predict progression or regression of atherosclerotic coronary artery disease. J Am Coll Cardiol (2001) 37:1871-6. doi:10.1016/S0735-1097(00)01199-2

61. Boullier A, Hamon M, Walters-Laporte E, Martin-Nizart F, Mackereel R, Fruchart JC, et al. Detection of autoantibodies against oxidized low-density lipoproteins and of IgG-bound low density lipoproteins in patients with coronary artery disease. Clin Chim Acta (1995) 238:1-10. doi:10.1016/0009-8981(95)06054-H

62. Uusitupa MI, Niskanen L, Luoma J, Vilja P, Mercuri M, Rauramaa R, et al. Autoantibodies against oxidized LDL do not predict atherosclerotic vascular disease in non-insulin-dependent diabetes mellitus. Arterioscler Thromb Vasc Biol (1996) 16:1236-42. doi:10.1161/01.ATV.16.10.1236

63. van de Vijver LP, Steyger R, van Poppel G, Boer JM, Kruijssen DA, Seidell JC, et al. Autoantibodies against MDA-LDL in subjects with severe and minor atherosclerosis and healthy population controls. Atherosclerosis (1996) 122:245-53. doi:10.1016/0021-9150(95)05759-5

64. Rossi GP, Cesari M, De Toni R, Zanchetta M, Maiolino G, Pedon L, et al. Antibodies to oxidized low-density lipoproteins and angiographically assessed coronary artery disease in white patients. Circulation (2003) 108:2467-72. doi:10.1161/01.CIR.0000097122.19430.48

65. Horkko S, Bird DA, Miller E, Itabe H, Leitinger N, Subbanagounder G, et al. Monoclonal autoantibodies specific for oxidized phospholipids or oxidized phospholipid-protein adducts inhibit macrophage uptake of oxidized low-density lipoproteins. J Clin Invest (1999) 103:117-28. doi:10.1172/ JCI4533

66. Chang MK, Bergmark C, Laurila A, Horkko S, Han KH, Friedman P, et al. Monoclonal antibodies against oxidized low-density lipoprotein bind to apoptotic cells and inhibit their phagocytosis by elicited macrophages: evidence that oxidation-specific epitopes mediate macrophage recognition. Proc Natl Acad Sci U S A (1999) 96:6353-8. doi:10.1073/pnas.96.11.6353

67. Engelbertsen D, Vallejo J, Quach TD, Fredrikson GN, Alm R, Hedblad $\mathrm{B}$, et al. Low levels of IgM antibodies against an advanced glycation endproduct-modified apolipoprotein B100 peptide predict cardiovascular events in nondiabetic subjects. J Immunol (2015) 195:3020-5. doi:10.4049/ jimmunol.1402869

68. Hernandez AM, Rodriguez N, Gonzalez JE, Reyes E, Rondon T, Grinan T, et al. Anti-NeuGcGM3 antibodies, actively elicited by idiotypic vaccination in nonsmall cell lung cancer patients, induce tumor cell death by an oncosis-like mechanism. JImmunol (2011) 186:3735-44. doi:10.4049/ jimmunol.1000609

69. Hernandez AM, Toledo D, Martinez D, Grinan T, Brito V, Macias A, et al. Characterization of the antibody response against NeuGcGM3 ganglioside elicited in non-small cell lung cancer patients immunized with an anti-idiotype antibody. JImmunol (2008) 181:6625-34. doi:10.4049/ jimmunol.181.9.6625

70. Vazquez AM, Hernandez AM, Macias A, Montero E, Gomez DE, Alonso DF, et al. Racotumomab: an anti-idiotype vaccine related to N-glycolylcontaining gangliosides - preclinical and clinical data. Front Oncol (2012) 2:150. doi: $10.3389 /$ fonc. 2012.00150

71. Vazquez AM, Rodreguez-Zhurbenko N, Lopez AM. Anti-ganglioside anti-idiotypic vaccination: more than molecular mimicry. Front Oncol (2012) 2:170. doi:10.3389/fonc. 2012.00170

72. Alfonso S, Valdes-Zayas A, Santiesteban ER, Flores YI, Areces F, Hernandez $\mathrm{M}$, et al. A randomized, multicenter, placebo-controlled clinical trial of racotumomab-alum vaccine as switch maintenance therapy in advanced non-small cell lung cancer patients. Clin Cancer Res (2014) 20:3660-71. doi:10.1158/1078-0432.CCR-13-1674

73. Weksler ME, Relkin N, Turkenich R, LaRusse S, Zhou L, Szabo P. Patients with Alzheimer disease have lower levels of serum anti-amyloid peptide antibodies than healthy elderly individuals. Exp Gerontol (2002) 37:943-8. doi:10.1016/S0531-5565(02)00029-3

74. Du Y, Dodel R, Hampel H, Buerger K, Lin S, Eastwood B, et al. Reduced levels of amyloid beta-peptide antibody in Alzheimer disease. Neurology (2001) 57:801-5. doi:10.1212/WNL.57.5.801 
75. Jianping L, Zhibing Y, Wei Q, Zhikai C, Jie X, Jinbiao L. Low avidity and level of serum anti-Abeta antibodies in Alzheimer disease. Alzheimer Dis Assoc Disord (2006) 20:127-32. doi:10.1097/00002093-200607000-00001

76. Dodel R, Balakrishnan K, Keyvani K, Deuster O, Neff F, Andrei-Selmer LC, et al. Naturally occurring autoantibodies against beta-amyloid: investigating their role in transgenic animal and in vitro models of Alzheimer's disease. J Neurosci (2011) 31:5847-54. doi:10.1523/JNEUROSCI.4401-10.2011

77. Congdon EE, Gu J, Sait HB, Sigurdsson EM. Antibody uptake into neurons occurs primarily via clathrin-dependent Fcgamma receptor endocytosis and is a prerequisite for acute tau protein clearance. J Biol Chem (2013) 288:35452-65. doi:10.1074/jbc.M113.491001

78. Chai X, Wu S, Murray TK, Kinley R, Cella CV, Sims H, et al. Passive immunization with anti-tau antibodies in two transgenic models: reduction of tau pathology and delay of disease progression. J Biol Chem (2011) 286:34457-67. doi:10.1074/jbc.M111.229633

79. Boutajangout A, Ingadottir J, Davies P, Sigurdsson EM. Passive immunization targeting pathological phospho-tau protein in a mouse model reduces functional decline and clears tau aggregates from the brain. JNeurochem (2011) 118:658-67. doi:10.1111/j.1471-4159.2011.07337.x

80. Bard F, Cannon C, Barbour R, Burke RL, Games D, Grajeda H, et al. Peripherally administered antibodies against amyloid beta-peptide enter the central nervous system and reduce pathology in a mouse model of Alzheimer disease. Nat Med (2000) 6:916-9. doi:10.1038/78682

81. DeMattos RB, Bales KR, Cummins DJ, Dodart JC, Paul SM, Holtzman DM. Peripheral anti-A beta antibody alters CNS and plasma A beta clearance and decreases brain A beta burden in a mouse model of Alzheimer's disease. Proc Natl Acad Sci U S A (2001) 98:8850-5. doi:10.1073/ pnas. 151261398

82. Siemers ER, Friedrich S, Dean RA, Gonzales CR, Farlow MR, Paul SM, et al. Safety and changes in plasma and cerebrospinal fluid amyloid beta after a single administration of an amyloid beta monoclonal antibody in subjects with Alzheimer disease. Clin Neuropharmacol (2010) 33:67-73. doi:10.1097/ WNF.0b013e3181cb577a

83. Doody RS, Thomas RG, Farlow M, Iwatsubo T, Vellas B, Joffe S, et al. Phase 3 trials of solanezumab for mild-to-moderate Alzheimer's disease. $N$ Engl J Med (2014) 370:311-21. doi:10.1056/NEJMoa1312889

84. Salloway S, Sperling R, Fox NC, Blennow K, Klunk W, Raskind M, et al. Two phase 3 trials of bapineuzumab in mild-to-moderate Alzheimer's disease. $N$ Engl J Med (2014) 370:322-33. doi:10.1056/NEJMoa1304839

85. Anand K, Sabbagh M. Early investigational drugs targeting tau protein for the treatment of Alzheimer's disease. Expert Opin Investig Drugs (2015) 24:1355-60. doi:10.1517/13543784.2015.1075002

86. Caraux A, Klein B, Paiva B, Bret C, Schmitz A, Fuhler GM, et al. Circulating human B and plasma cells. Age-associated changes in counts and detailed characterization of circulating normal CD138- and CD138+ plasma cells. Haematologica (2010) 95:1016-20. doi:10.3324/ haematol.2009.018689

87. Chong Y, Ikematsu H, Yamaji K, Nishimura M, Nabeshima S, Kashiwagi S, et al. CD27(+) (memory) B cell decrease and apoptosis-resistant CD27(-) (naive) B cell increase in aged humans: implications for age-related peripheral B cell developmental disturbances. Int Immunol (2005) 17:383-90. doi:10.1093/intimm/dxh218

88. Colonna-Romano G, Bulati M, Aquino A, Pellicano M, Vitello S, Lio D, et al. A double-negative (IgD-CD27-) B cell population is increased in the peripheral blood of elderly people. Mech Ageing Dev (2009) 130:681-90. doi:10.1016/j.mad.2009.08.003

89. Veneri D, Ortolani R, Franchini M, Tridente G, Pizzolo G, Vella A. Expression of $\mathrm{CD} 27$ and $\mathrm{CD} 23$ on peripheral blood $\mathrm{B}$ lymphocytes in humans of different ages. Blood Transfus (2009) 7:29-34. doi:10.2450/2008.0007-08

90. Holodick NE, Rothstein TL. B cells in the aging immune system: time to consider B-1 cells. Ann N Y Acad Sci (2015) 1362:176-87. doi:10.1111/ nyas. 12825
91. Yang Y, Wang C, Yang Q, Kantor AB, Chu H, Ghosn EE, et al. Distinct mechanisms define murine $\mathrm{B}$ cell lineage immunoglobulin heavy chain (IgH) repertoires. eLife (2015) 4:e09083. doi:10.7554/eLife.09083

92. Witztum JL, Lichtman $\mathrm{AH}$. The influence of innate and adaptive immune responses on atherosclerosis. Annu Rev Pathol (2014) 9:73-102. doi:10.1146/ annurev-pathol-020712-163936

93. Binder CJ, Horkko S, Dewan A, Chang MK, Kieu EP, Goodyear CS, et al. Pneumococcal vaccination decreases atherosclerotic lesion formation: molecular mimicry between Streptococcus pneumoniae and oxidized LDL. Nat Med (2003) 9:736-43. doi:10.1038/nm876

94. Chou MY, Fogelstrand L, Hartvigsen K, Hansen LF, Woelkers D, Shaw PX, et al. Oxidation-specific epitopes are dominant targets of innate natural antibodies in mice and humans. J Clin Invest (2009) 119:1335-49. doi:10.1172/ JCI36800

95. Wang C, Turunen SP, Kummu O, Veneskoski M, Lehtimaki J, Nissinen AE, et al. Natural antibodies of newborns recognize oxidative stress-related malondialdehyde acetaldehyde adducts on apoptotic cells and atherosclerotic plaques. Int Immunol (2013) 25:575-87. doi:10.1093/intimm/dxt022

96. Morris DL, Rothstein TL. Abnormal transcription factor induction through the surface immunoglobulin M receptor of B-1 lymphocytes. J Exp Med (1993) 177:857-61. doi:10.1084/jem.177.3.857

97. Hayakawa K, Asano M, Shinton SA, Gui M, Wen LJ, Dashoff J, et al. Positive selection of anti-thy-1 autoreactive B-1 cells and natural serum autoantibody production independent from bone marrow B cell development. J Exp Med (2003) 197:87-99. doi:10.1084/jem.20021459

98. Hardy RR. B-1 B cell development. JImmunol (2006) 177:2749-54. doi:10.4049/jimmunol.177.5.2749

99. Libbey JE, Peterson LK, Tsunoda I, Fujinami RS. Monoclonal MOGreactive autoantibody from progressive EAE has the characteristics of a natural antibody. J Neuroimmunol (2006) 173:135-45. doi:10.1016/j. jneuroim.2005.12.010

100. Baumgarth N. The double life of a B-1 cell: self-reactivity selects for protective effector functions. Nat Rev Immunol (2011) 11:34-46. doi:10.1038/nri2901

101. Herzenberg LA. Layered evolution in the immune system: a view from history. Ann N Y Acad Sci (2015) 1362:1-5. doi:10.1111/nyas.12795

102. Martin F, Oliver AM, Kearney JF. Marginal zone and B1 B cells unite in the early response against $\mathrm{T}$-independent blood-borne particulate antigens. Immunity (2001) 14:617-29. doi:10.1016/S1074-7613(01)00129-7

103. Bagnara D, Squillario M, Kipling D, Mora T, Walczak AM, Da Silva L, et al. A reassessment of IgM memory subsets in humans. J Immunol (2015) 195:3716-24. doi:10.4049/jimmunol.1500753

104. Weller S, Braun MC, Tan BK, Rosenwald A, Cordier C, Conley ME, et al. Human blood IgM "memory" B cells are circulating splenic marginal zone B cells harboring a prediversified immunoglobulin repertoire. Blood (2004) 104:3647-54. doi:10.1182/blood-2004-01-0346

105. Capolunghi F, Rosado MM, Sinibaldi M, Aranburu A, Carsetti R. Why do we need IgM memory B cells? Immunol Lett (2013) 152:114-20. doi:10.1016/j. imlet.2013.04.007

106. Hardy RR, Hayakawa K. Positive and negative selection of natural autoreactive B cells. Adv Exp Med Biol (2012) 750:227-38. doi:10.1007/978-1-4614-3461-0_17

Conflict of Interest Statement: The author declares that the research was conducted in the absence of any commercial or financial relationships that could be construed as a potential conflict of interest.

Copyright $\odot 2016$ Rothstein. This is an open-access article distributed under the terms of the Creative Commons Attribution License (CC BY). The use, distribution or reproduction in other forums is permitted, provided the original author(s) or licensor are credited and that the original publication in this journal is cited, in accordance with accepted academic practice. No use, distribution or reproduction is permitted which does not comply with these terms. 